\title{
Micromorphology and Maturation of the Yellow Granules in the Hornet Gastral Cuticle
}

\author{
Marian Plotkin ${ }^{1, \#}$, Stanislav Volynchik ${ }^{1}$, Zahava Barkay ${ }^{2}$, David J. Bergman ${ }^{3}$, Jacob S. Ishay ${ }^{1, *}$ \\ (1. Department of Physiology and Pharmacology, Sackler Faculty of Medicine, Tel-Aviv University, Ramat Aviv 69978, Israel; 2. Wolfson \\ Applied Materials Research Center, Tel-Aviv University, Ramat Aviv 69978, Israel; 3. School of Physics and Astronomy, Raymond \\ and Beverly Sackler Faculty of Exact Sciences, Tel-Aviv University, Ramat Aviv $\quad 69978$, Israel)
}

\begin{abstract}
The yellow granules in the gastral cuticle of the Oriental hornet Vespa orientalis (Hymenoptera, Vespinae) are located in yellow stripes. In the present study, we focus on the micromorphology and formation of the yellow granules from their inception to their spread in the regions which are destined to acquire a yellow color. The cuticle was observed with several methods of electron microscopy. The results showed that the yellow granules comprise a layer which is 20-25 $\mu \mathrm{m}$ thick, within the total cuticular thickness of 40-45 $\mu \mathrm{m}$. In the mentioned regions one can see, from above, many apertures of about $0.5 \mu \mathrm{m}$ in diameter which extends into a peripheral photoreceptor cell. In each yellow granule, one discerns a myoid envelope inside which there are 9 fibrils arranged in a circle. Yellow granules maturation process involves infiltration of canals that give rise to the incipient ball-shaped primary granules which increase in number (as a result of continues budding off the walls of a canal) as the cuticle matures and transform into secondary barrel shaped granules, becoming elongated and then splitting into shorter barrels that fill up the entire area. Preliminary examinations have suggested liver-like function activity within the layer of yellow granules.
\end{abstract}

Key words: Micromorphology; Cuticle; Yellow granules; Peripheral photoreceptor; Oriental hornet Vespa orientalis

\section{黄蜂胃部表皮黄色颗粒的微观形态与发育}

\author{
Marian Plotkin $^{1, \# \text {, Stanislav Volynchik }}{ }^{1}$, Zahava Barkay ${ }^{2}$, David J. Bergman ${ }^{3}$, Jacob S. Ishay ${ }^{1, *}$ \\ (1. Department of Physiology and Pharmacology, Sackler Faculty of Medicine, Tel-Aviv University, Ramat Aviv 69978, Israel; 2. Wolfson \\ Applied Materials Research Center, Tel-Aviv University, Ramat Aviv 69978, Israel; 3. School of Physics and Astronomy, Raymond
} and Beverly Sackler Faculty of Exact Sciences, Tel-Aviv University, Ramat Aviv 69978, Israel)

摘要: 东方大黄蜂 (胡蜂) Vespa orientalis（膜翅目 Vespinae 属）的胃部表皮黄色颗粒位于黄色条纹区域。从 黄色颗粒产生至在这一区域扩散, 这个过程就是胃部黄颜色形成的过程。用几种电子显微镜研究了黄色颗粒的微 观形态和发育过程。结果显示黄色颗粒由 $20-25 \mu \mathrm{m}$ 厚的一层组成, 包括总表皮在内厚度约为 $40-45 \mu \mathrm{m}$ 。从上 面看, 在上述的区域能看到许多直径大约为 $0.5 \mu \mathrm{m}$ 周边光感受器细胞(PPC)。在每个黄色颗粒, 能观察到一个肌 样包膜, 它位于一个由 9 根原纤维组装而成的圆圈内部。黄色颗粒成熟的过程包含通过导管的渗透增加初生黄色 粒子数量，这些初生粒子又发育或增生成次生粒子，次生粒子逐渐布满整个区域。在这些黄色粒子层内可产生类 似于肝的功能活动。

关键词: 微观形态; 表皮; 黄色颗粒; 周边光感受器; 东方大黄蜂

中图分类号：Q959.483 文献标识码：A 文章编号：0254-5953-(2009)01-0065-09

The Oriental hornet Vespa orientalis is a social insect whose distribution extends from the Near East up to India (Bodenheimer, 1933). The hornet is a colorful insect whose cuticle bears the colors brown and yellow. The yellow colors occur on the frons and clypeus plates (on the head), as well as on the gaster, where they appear on the dorsal aspect in stripe form on gastral segments $3+4$ and on the ventral aspect as a single stripe on segment 3 (Fig. 1A).

The brown cuticle is composed of approximately 30

\footnotetext{
Received date: 2008-09-05; Accepted date: 2009-01-04

*Corresponding author (通讯作者), E-mail: physio7@post.tau.ac.il

${ }^{\#}$ This work was performed in partial fulfillment of the requirements for a PhD degree of Marian Plotkin, Sackler Faculty of Medicine, Tel-Aviv University, Israel.

收稿日期：2008-09-05; 接受日期：2009-01-04
} 

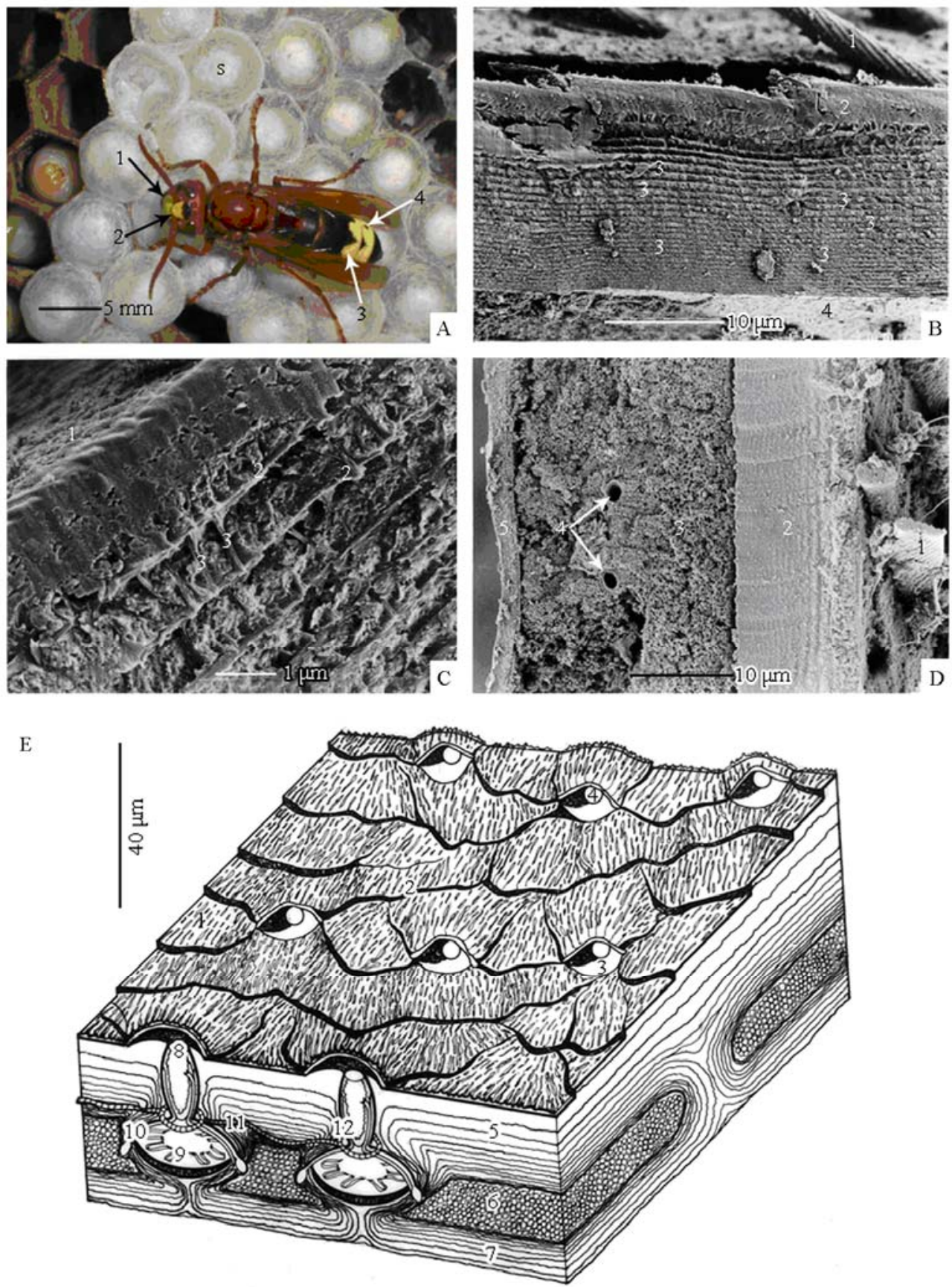

Fig. 1 Details of the structural difference between a yellow stripe and brown cuticle of an adult hornet A: Showing a hornet resting upon a "carpet" of silk caps (s). The hornet bears yellow areas on the cuticle on the clypeus (1) the frons (2) on the dorsal aspect of the $3 \mathrm{rd} \& 4$ th gastral segments $(3 \& 4)$ vental aspect of the 3 rd yellow gastral segment is not shown in picture. Bar $=5 \mathrm{~mm}$. B: Cross-section through brown cuticle shows hairs (1) exocuticle (2) endocuticle (3) hypocuticle (4) Bar $=10 \mu \mathrm{m}$.

C: At higher magnification, one can see that beneath the layer of exocuticle (1) lamellae (2) and vertical partitions (3) Bar=1 $\mu \mathrm{m}$.

D: Cross-section through a cuticle containing yellow granules. One can see the hairs (1) exocuticle and the endocuticle (2) the layer of yellow granules (3) tracheae (4) and hypocuticle (5) Bar=10 $\mu \mathrm{m}$.

E: A graphic presentation showing structure of the yellow stripe and of the PPC.

The epicuticle (1) has parallel structures that are perpendicular to the conduction lines (2) Between the lines are flat surfaces resembling a parabolic mirror (3) and a rounded opening of the PPC (4) In cross section one can see the lamellae (5) mass of yellow granules (6) hypocuticle (7) In the PER there is an extension that reaches to below the top layers of the cuticle (8) At the base of the PER are regions of the rhabdom that resemble a horseshoe in shape (9) nerves extending (10) tracheal elements that form a loop (11) and also interconnect them (12) Bar=40 $\mu \mathrm{m}$. 
lamellae whose thickness diminishes as one proceeds from the exterior inwards (i.e. from the exocuticle to the hypocuticle, Fig. 1B,C) (Ishay et al, 1999). On the other hand, the yellow cuticle is composed of only approximately 15 lamellae (comprising the exo-and endocuticle), beneath which there is a layer of yellow granules whose thickness is approximately $20-25 \mu \mathrm{m}$, and beneath this a hypocuticle $(-0.5 \mu \mathrm{m}$ in thickness) (Fig. 1D). In the yellow cuticle are discernible peripheral photoreceptors (PPCs), which open into the exocuticle but are actually located in the layer of yellow granules (Fig. 1E). The colorfulness of hornets has been known for a long time. Guiglia (1972) believed that these are colors intended to warn off insectivores. In the different species of social hornets and wasps and in many different solitary ones the color stripes may occur in different parts of the body. As already mentioned, in $V$. orientalis there are only two yellow stripes on the dorsal aspect of the gaster, but in the related species $V$. crabro, each of the gastral segments bears a yellow stripe and there are also yellow stripes on the other parts of its body (Spradbery, 1973). In various species of Vespinae yellow stripes are evident, but also in species of Polistinae.

We have shown that the Oriental hornet eclodes bearing a pale coloration and only gradually (within a few days) do its body segments acquire a distinct brown or yellow coloration. In fact, the ecloding worker hornet does not fly out of the nest before its colors become fast and prominent. In the present study, we followed the nascence of the layer of yellow granules from its incipience in the gastral segments to its ultimate repletion of yellow granules. The micromorphology of the layer and its granules is also traced and explained.

\section{Materials and methods}

\subsection{Preparation of hornet age groups for examination}

Adult hornets and brood in combs were collected from the field during the active season of hornets as previously described (Ishay, 1964). Worker hornet resting on a comb was photographed via Konica Minolta Z1 (Fig. 1A). In the laboratory the brood combs were separated from the collected adults and the worker hornets ecloding on each day were collected. Every newly-emerged batch of hornets was now kept in a separate breeding box, thus providing us with age groups ranging from zero hour to several days old. Hornets prior to eclosion were obtained by removal of the silk cap from the pupal cell and their age adjudged from their color and phase of development (e.g., with or without wing buds). Thus we obtained pupae at various developmental stages, prior to eclosion, namely, 48-24 hrs, and $24-0$ hrs, as well as a group of newly ecloded imagines aged 0-24 hrs (post eclosion).

\subsection{Preparation for scanning electron microscope (SEM)}

Specimens were prepared according to the TAO (tannic acid/arginine/osmium tetroxide) non-coating technique, which involved immersion of the samples in a mixture of arginine- $\mathrm{HCl}$, glycine, sucrose and sodium glutamate $\left[2 \%, 16 \mathrm{~h}, 20^{\circ} \mathrm{C}\right]$, rinsing $(3 \times)$ in distilled water and immersion in a mixture of tannic acid and guanidine- $\mathrm{HCl}\left[2 \%, 8 \mathrm{~h}, 20^{\circ} \mathrm{C}\right]$, after which the samples were carefully rinsed $(3 \times)$ in distilled water. Finally tissues were fixed by immersion in an $\mathrm{OsO}_{4}$ solution in distilled water $\left[2 \%, 8 \mathrm{~h}, 20^{\circ} \mathrm{C}\right]$, followed by rinsing $(3 \times)$ in distilled water, as described previously (Jongebloed \& Kalicharan, 1994). Dehydration with ethanol was followed by critical point drying (CPD) in liquid $\mathrm{CO}_{2}$. Observations were carried out with a JEOL FE-SEM, type 630IF, operated at $2-3 \mathrm{kV}$ (Fig. 1B-D, 2E, 3F, H).

\subsection{Preparation for transmission electron microscopy (TEM)}

Small portions of previously observed FE-SEM samples, prepared according to the GA/PF/Acrolein pre-fixation and the TAO post-fixation procedure, were carefully orientated, embedded in Epon and ultrathin sectioned. Sections were post-stained with uranyl acetate/lead citrate and observed in a Philips TEM, type CM 100,operated at $60 \mathrm{kV}$ (Fig. 2C, D, F).

\subsection{Preparation for environmental scanning electron microscope (ESEM)}

Yellow stripes were excised from adult hornets more than three days post eclosion and pupae at various developmental stages, prior to eclosion, and these stripes were viewed via the Quanta 200 FEG environmental scanning electron microscope (ESEM). In order to examine the samples as close as possible to their natural state, we avoided covering the sample with a conducting thin layer of heavy metals but rather used low vacuum mode. The samples were imaged with the secondary electron large-field detector (LFM) in low vacuum mode of $70 \mathrm{~Pa}$. Due to great sensitivity of the biological sample to high beam exposure dose, the images were taken at relatively quick scan rates (10-20s per frame), at low magnification when possible, and each region was 
exposed once (Fig. 2A, B, 3A-E, G).
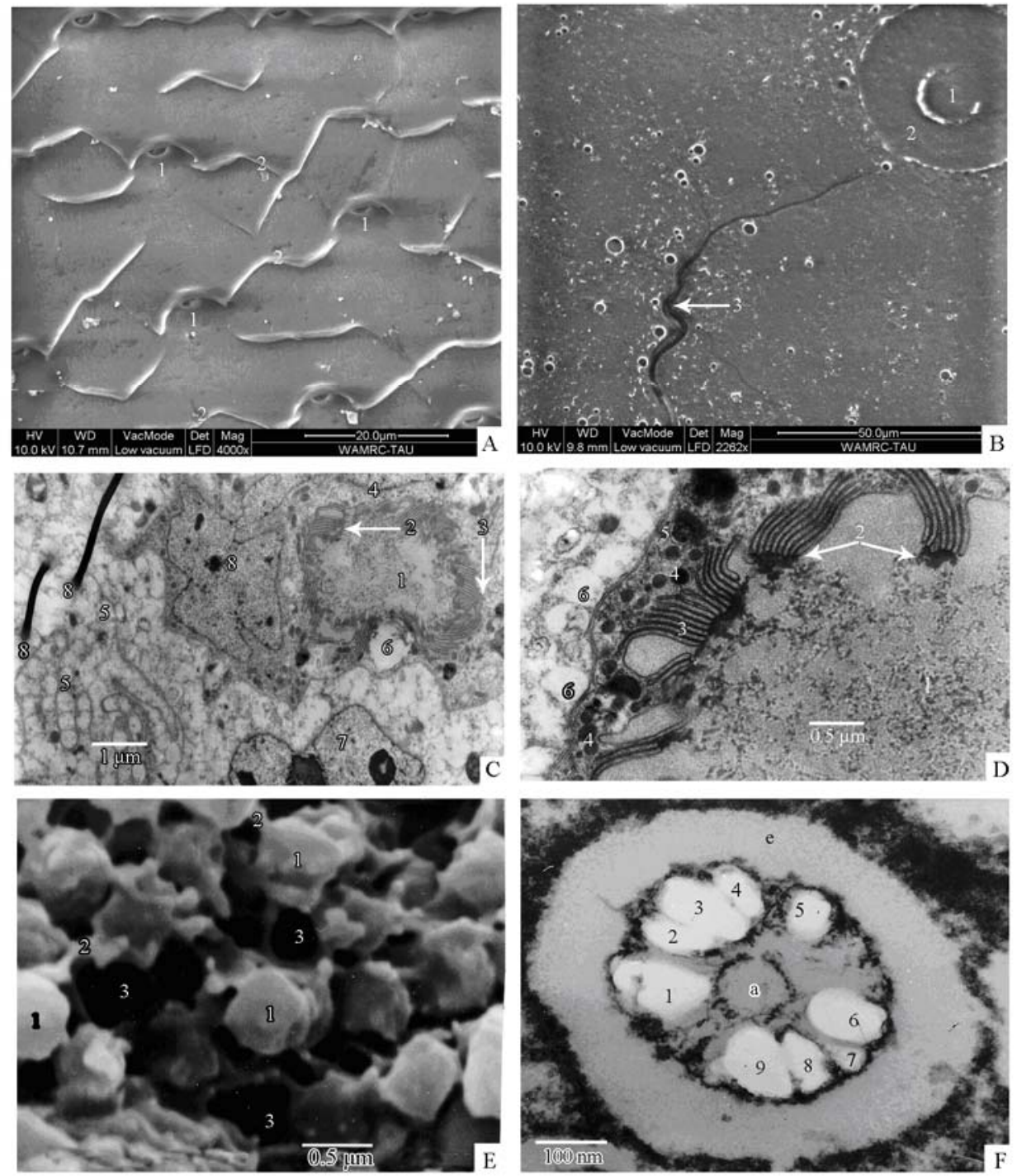

Fig. 2 Structure of a yellow cuticle

A: The exocuticle of a yellow stripe, with the apertures of peripheral photoreceptors (PPCs) disernible (1) Also visible are protrusions (2) dividing the surface of the yellow stripe into polygons. Bar $=20 \mu \mathrm{m}$.

B: Eversion of the cuticle so as to view its underside enables to see the PPC from its basal part. The center of the PPC (1) the envelopes enwrapping the PPC (2) nerve fiber (3). Bar $=50 \mu \mathrm{m}$.

C: cross-section through a PPC showing its center (1) and around it the enwrapping membranes with "burnt" edges (2) Granules containing melanin (3) membrane (4) yellow granules (5) A neuron (6) the nucleus of another cell (7) and two nerve fibers (8). Bar=1 $\mu \mathrm{m}$.

D: Higher magnification of the PPC enables to discern that around the center of the PPC (1) "burnt" edges of microfibrils (2) microfibrils resemble a horseshoe in shape (3) melanin containing granules (4) membrane enwrapping the PPC (5) and yellow granules (6). Bar=0.5 $\mu \mathrm{m}$.

E: view of a yellow region showing the dense network of yellow granules (1) which are interconnected by extensions (2) The spaces between the yellow granules (3) are filled with flowing hemolymph. Bar $=0.5 \mu \mathrm{m}$.

F: Cross-section through a yellow granule revealing its structure, namely, a central axoneme (a) encircled by nine microfibrils (1-9), the whole enwrapped within a myoid envelope (e). Bar=100nm.

\subsection{Preparation for enzymatic analysis}

Worker hornets $(30$ specimens, all from the same colony) were exposed to UV illumination at a distance of $5-7 \mathrm{~cm}$ from the UV lamp $\left(\lambda=366 \mathrm{~nm}: 1.2 \mathrm{~mW} / \mathrm{cm}^{2}\right.$, Minuvis, Desaga, Heidelberg), for 3 hours. In parallel, 30 other worker hornets were kept in the dark as control. Next, the two yellow stripes (gastral segments 2 and 3) from the gaster of each hornet were excised by use of delicate scissors and the yellow matter from the interior, soft part of the cuticle was scraped off with a scalpel. 

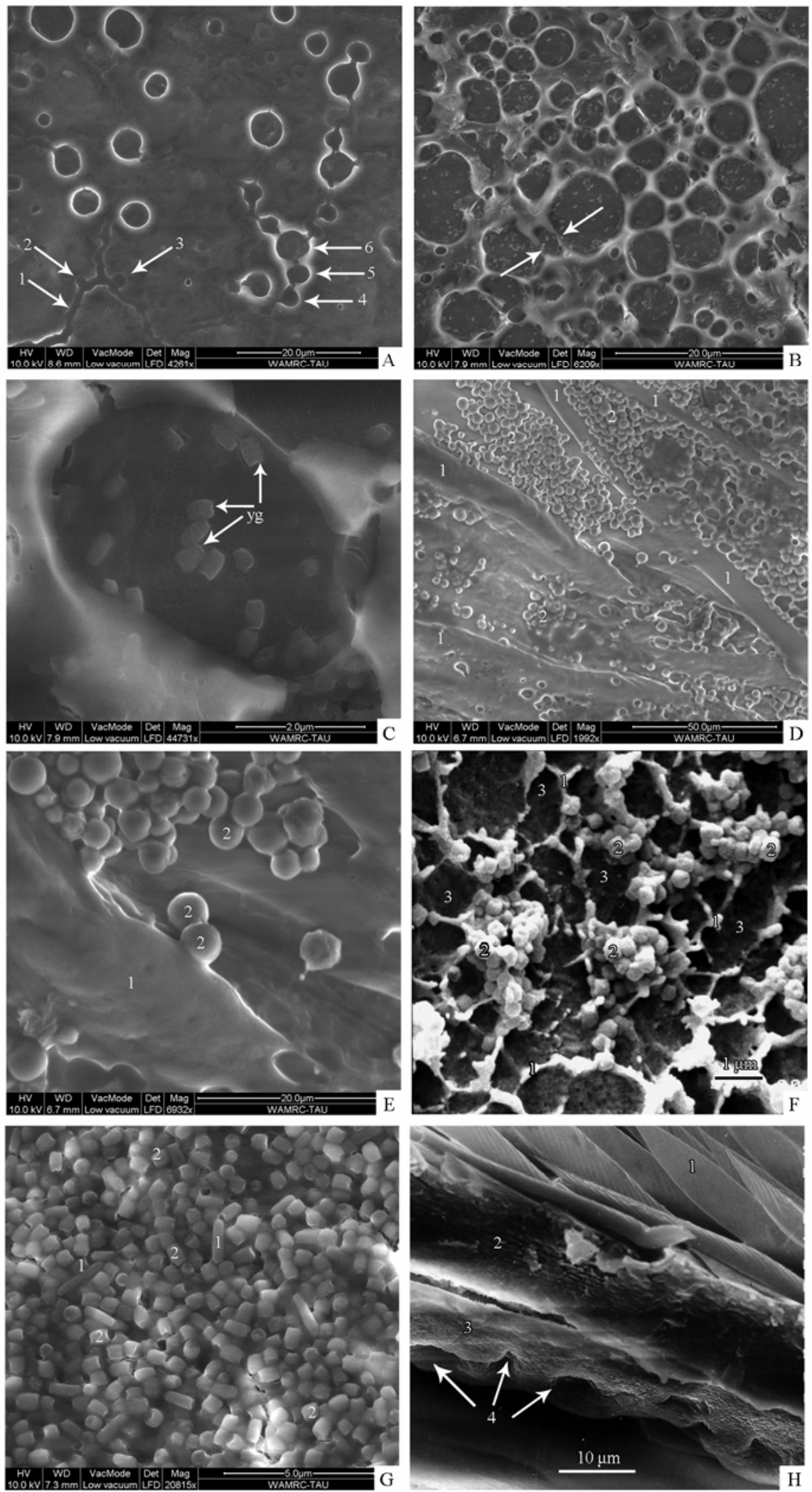

Fig. 3 Pictures showing the creation of spaces in the cuticle infiltrated and filled by yellow granules

The process is traced in hornets 48 to 24 hours prior to eclosion (A) and zero to 24 hours post eclosion (B, C). Maturation of yellow granules is shown (D-H) A: Picture showing the incipience of bubble-shaped spaces. The "bubbles" are interconnected by a system of canals. The process of "bubble" formation can be traced: first, canals make this appearance (1) upon which bulges begin to appear $(2,3)$ and these become ever bigger $(4,5,6)$ 


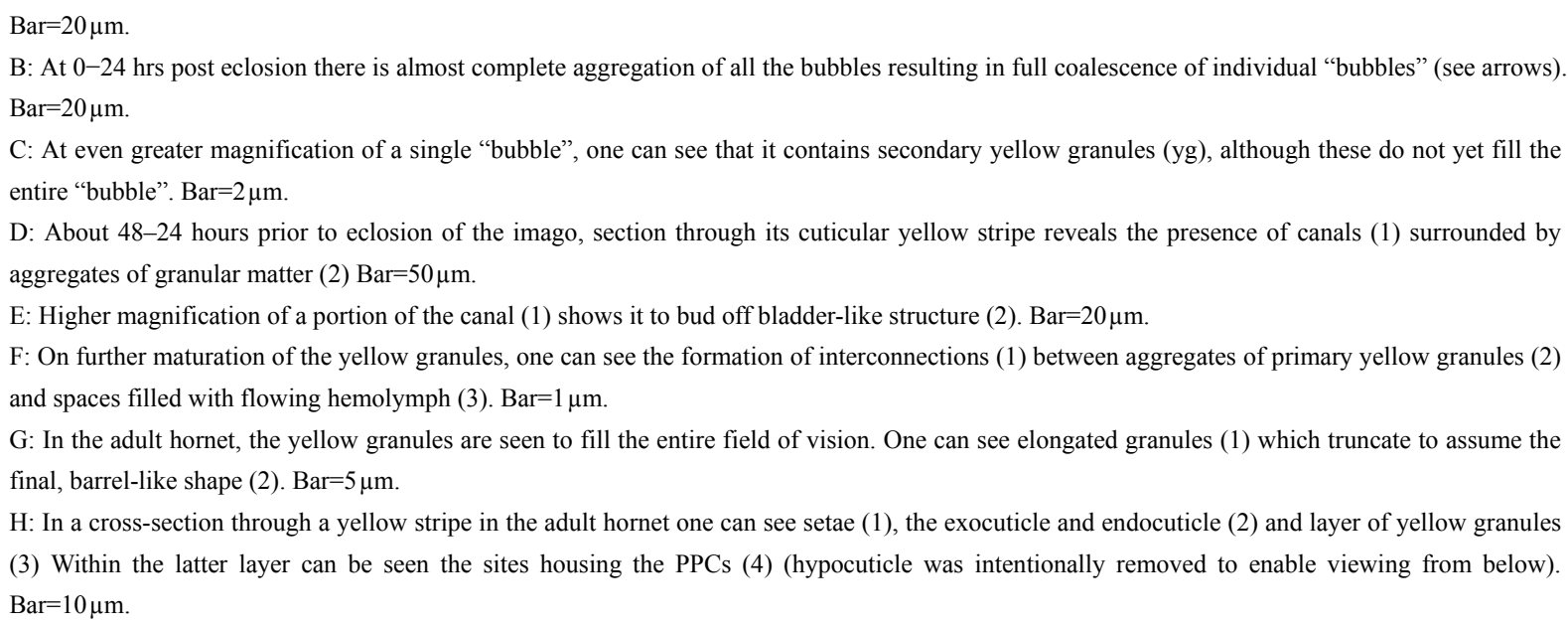

Following this, hemolymph was collected via capillary pipette from the aorta. All the collected material from the various test and control hornets, yellow granules and hemolymph separately were combined for the purpose of chemical determinations. The materials were kept in the dark under refrigeration $\left(-5^{\circ} \mathrm{C}\right)$ until the next morning and then subjected to biochemical evaluation, after adjusting the volume, if needed, to $0.5 \mathrm{~mL}$ of liquid by mammalian saline. The biochemical determinations were made via a Roche Hitachi 705, which is a fully automated, discrete, computerized chemistry analyzer intended for in vitro diagnostic use in quantitative determination of serum constituents. The determinations were run in parallel on material kept in light and material kept in the dark.

\section{Results}

\subsection{Micromorphology of the yellow stripe in the adult Oriental hornet}

Viewing the exocuticle from the exterior (top view) reveals the outlets of peripheral photoreceptor cells (PPCs) and of convoluted protrusions that partition the cuticle into polygons, which in turn divide the cuticle into straight plates, despite the fact that in cross-section the hornet body is rounded. Viewing the cuticle from the underside reveals the circular form of the PPC. The center of the PPC amenable to direct illumination, it contains a congregation of light-sensitive membranes whose outer portions had been "burnt out". The rhabdomeric microvilli form a horseshoe shape and in the fold of the "horseshoe" there is a space housing a lens. One can discern pigment granules on the exterior of the PPC, probably comprised of melanin. The PPC is enclosed by an outer membrane around which are densely packed yellow granules, a neural connection situated below the PPC which indicate that the nerve fibers are forming a synapse with the PPC. Nerve fibers interconnect between the various PPCs in this region. The yellow granules adhere to the outer part of the PPC and are interconnected to one another by horizontal extensions that also bond between adjacent PPCs, with the PPCs themselves immersed within hemolymph. In a cross-section through a yellow granule, one can see that central axoneme is surrounded by nine microfibrils all of them are surrounded by an envelope.

\subsection{The maturation process of the yellow stripe}

Tearing apart of the upper cuticle (i.e., the epicuticle, exocuticle and numerous layers of the endocuticle) of worker hornets at 48-24 hours before eclosion reveals the presence of bubble-shaped pockets which in some places are extended, suggesting the penetration of "phagocytic cells" that absorb the cuticular matter, paving the way for the infiltration of yellow granules. At 0-24 hours post eclosion the "bubbles" occupy most of the observed cuticular area, and as they grow in size they conflate and start to fill up with yellow granules. At this stage, the yellow granules do not yet occupy the entire field of vision and subsequently, in the "older" hornet, the "bubbles" coalesce completely and are no longer seen as separate entities. Tracing the genesis of the yellow granules at 48-24 hours prior to eclosion of the vespan imago and up to 3 days post eclosion shows that in the spaces created in the hornet cuticle develop elongated canals surrounded by aggregates of primary yellow granules, that is, granules that appear rounded rather than barrel-shaped. Primary yellow granules are budding off the walls of a canal. Later on, the maturing of the cuticle the yellow granules arrange into a complex network comprised of string-like structures that interconnect between the yellow granules. Following 
eclosion the primary yellow granules transform into secondary yellow granules, i.e., the primary granules changing from rounded shape into barrel shaped, becoming elongated and then splitting into shorter barrels assuming the final form of the mature, uniform and uncompartmentalized structure of a yellow stripe.

\subsection{Presence of liver-like enzymes in yellow granules and in the hemolymph}

In the course of the present study, we also collected yellow granules from worker hornets. These were crushed in order to ascertain their enzymatic content and compared to the enzymatic content of their hemolymph. This endeavor was of a preliminary nature and of limited scope, but yielded some interesting results, meriting mention here. We have summarized these results in Tab. 1, which compares the enzymatic content of the yellow granules with that of the hemolymph in which they are immersed. The enzymatic activity was compared between these hornets kept in light versus those kept in the dark.

\section{Discussion}

As already mentioned in the introduction, the hornet is coated with a cuticle composed of two primary types, namely, a brown and yellow cuticle. In both types, the cuticle is comprised of lamellae whose thickness

Tab. 1 The presence of liver-like enzymes in yellow granules and in the hemolymph of hornets kept in UV light as compared to those kept in the dark

\begin{tabular}{|c|c|c|c|c|c|}
\hline \multirow{2}{*}{ Enzymes \& Glucose } & \multicolumn{2}{|c|}{ Yellow granules extract } & \multicolumn{2}{|c|}{ Hemolymph } & \multirow{2}{*}{ Reference } \\
\hline & Darkness & Light & Darkness & Light & \\
\hline Glucose (mg/L) & 430 & 1640 & 12320 & 14100 & Fischl \& Ishay, 1971 \\
\hline LDH (lactate dehydrogenase, EC1.1.1.27) (IU/L) & 501 & 53 & 601 & 412 & Wroblewski \& Due, 1953 \\
\hline ALT (alanine aminotransferase, EC 2.6.1.2) (IU/L) & 1210 & 910 & 74 & 96 & Rej \& Vanderlinde, 1975 \\
\hline AST(aspartate aminotransferase, EC 2.6.1.1) (IU/L) & 1015 & 965 & 170 & 174 & Bergmeyer et al, 1978 \\
\hline TPR (total protein) $(\mathrm{mg} / \mathrm{L})$ & \multicolumn{2}{|c|}{7120} & \multicolumn{2}{|c|}{6820} & Present study \\
\hline
\end{tabular}

diminishes towards the interior of the body. In the yellow cuticle, part of the cuticular space is occupied by a mass of yellow granules situated between several lamellae of the endocuticle and the hypocuticle. A graphic presentation of the yellow cuticle is provided in Fig. 1E. $\mathrm{Be}$ it brown or yellow cuticle, the surface of the cuticle is not smooth (Fig. 2A), but rather marked with the apertures of the PPCs (1), as well with protrusions enclosing polygon- shaped areas (2). At the other end of the PPC, containing the photoreceptory apparatus, one can see in Fig. 2B two concentric circles, the inner one (1) indicating the site reached by a light beam and the outer one (2), where the rhabdomeres are situated (Fig. 2C, D) (Ishay et al, 2004). Bees PPC is made of eight cells (Snyder \& Pask, 1972). We have yet to ascertain how many cells make up a PPC in the Oriental hornet, but even so, it is clear that it is an open rhabdome, with all the ordinary components, including a fixed site, at the margins of the rhabdomere, which houses a lens. We have as yet no further details regarding the lens in the PPC, but the affinity of the yellow granules to the membrane enwrapping the PPC is clearly visible (Fig. $2 \mathrm{C}, \mathrm{D})$. Elsewhere in the cuticle yellow stripe, the yellow granules are numerous and ubiquitous, and seem to be interconnected in two ways, namely, by a string-like structure passing through the center of the granule-the axoneme- and comprising the vertical connectors, as well by extensions budding off their exterior and linking up to the myoid of neighboring granules, and comprising the horizontal connector. The number of connections is considerable on all sides of the mature yellow granules. We note also that all the granules are fully immersed in hemolymph (Fig. 2E). At greater magnification, each granule is seen to possess an outer shell (myoid), and internally - nine microfibrils arranged in a circle (as in a cilium), and at the center - a clearly circular axoneme but without visible microfibrils (Fig. 2F).

A few days prior to eclosion of the imago, there is incipient creation of "bubbles" within the cuticle (Fig. $3 \mathrm{~A})$ which continue to grow until they create a space within the cuticle (Fig. 3B, C) which allows the yellow granules to enter.

When one traces the formation of the yellow granules (Fig. 3D), one can observe at 48-24 hrs prior to eclosion of the hornet, the appearance of canals (1), which are surrounded by primary yellow granules (2) those primary granules are discharged to the spaces created earlier (Fig. 3A-C). These are shown at higher magnification in Fig. 3E, where 1-canal and 2-primary granules. The primary yellow granules give rise to 
secondary yellow granules that now fill the entire space and are interconnected.

This process continues until the Oriental hornet is 3-4 days old (post eclosion) and ready to exit the nest, by now, the Oriental hornet undergone through two major changes: 1) Proliferation - as a result of continues budding off from the walls of a canal, this causes the hollow in the cuticle created earlier to fill with primary rounded granules. As the cuticle continue to mature, the granules go through a second major change. 2) maturation - the incipient rounded primary granules changed their shape and become barrel-shaped secondary granules). It stands to reason that the binding in our case serves a purpose, and we suspect that the interconnecting strings (Fig. 3F) transport something from one place to another. In the adult hornet the yellow granules ultimately fill the entire area (Fig. 3G). Most of the granules are short, of about $0.5 \mu \mathrm{m}$ in length (2), but there are still some granules of greater length, such as have not yet truncated (1) (Fig. 3H). Top view of the cuticle reveals it to be dotted with the apparatus of PPCs, yet each PPC, has it own separate aperture (Fig. 2A) and its own rhabdomeres at its base. However, upon maturation of the yellow granules, it becomes hard to distinguish which belong to which PPC. Rather, they form a single mass, about $25 \mu \mathrm{m}$ thick, which extends underneath the entire stripe of yellow cuticle (Fig. 3H). In fact, the only place where the mass of yellow granules thins out is in the region of the PPCs.

Becker (1937) identified in the cuticular yellow matter the pigment pterine and conjectured that it may have reached the cuticle after extrusion from the yellow granules. Earlier studies by us (Ikan \& Ishay, 1967) found the yellow cuticle to contain xanthopterin. Xanthopterin is found in high concentrations in Arthropods (Schliva \& Euteneuer, 1979; Wijnen et al, 2007) and lower vertebrates (Le Guyader \& Jesuthasan, 2002). The creation of pigment cells in vertebrates has been extensively studied (Bagnara et al, 1979;

\section{References:}

Bagnara JT, Matsumoto J, Ferris W, Frast SK, Turner WA Jr, Tchen TT, Taylor JD. 1979. Common origin of pigment cells [J]. Science, 203: 410-415.

Becker E. 1937. Über das Pterinpigment bei Insekten und die Fărbung und Zeichnung von Vespa im Besonderen [J]. Zeitschrift für Morphology und Ökologie fon Tiere, 33: 672-751.

Bergmeyer HU, Scheibe P, Wahlefeld AW. 1978. Optimization of methods for aspartate aminotransferase and alanine aminotransferase $[\mathrm{J}]$.
Bronner-Fraser, 1994) and the prevalent opinion is that they are formed by the migration of cells from the neural crest of the developing embryo. Pteridines were studied extensively in the wings of pierid butterflies, where, the pterin pigment granules (also called pterinisomes) are located at extracellular framework of the scales. In hymenopteran insects such as the Oriental hornet very little is known about pteridine biosynthesis. In our case, the granules are probably created by the endoplasmic reticulum which, in the hornets, develops as rows of microtubules, and these give rise to bladders that house the pigment cells until their maturation, so that several days after eclosion, usually about 3-4 days (unpublished data), the young hornet can fly out of the nest without fear of being harmed by insolation. As to the role played by the yellow granules in hornets, we conjecture that since they aggregate en masse around what have variously been called extraretinal photoreceptors.

As for the detected enzymatic activity in the yellow granules, our preliminary findings point to the occurrence in them not encountered in the hemolimph (in the same level) or any other part of the body. Ordinarily one would expect to find in invertebrates the enzymatic activity of a fat body. In other hornets (workers), however, there is neither fat body nor a hepatopancreas. Our preliminary findings suggest that in hornet cuticle, in the region of the yellow stripes, there is a quasi-liver function enzymatic activity which somehow seems to be light-dependent. The exact nature of their activity, the enzymes involved and the mechanism responsible for it have yet to be ascertained and merit further, in-depth study. What we know thus far is that hornet flight activity has a strong correlation with UVB radiation level (Volynchik et al, 2008).

Acknowledgements: We thank the Mirzoeff \& Sons Foundation for their financial support. We thank the Israeli Ministry of Immigrant absorption for their generous support of Dr. Stanislav Volynchik.
Clinical Chemistry, 24: 58-74.

Bodenheimer FS. 1933. Über die aktivit?t von Vespa orientalis L. in Jahresverlauf in Palaestina [J]. Zoologischer Anzeiger, 102: 135-140.

Bronner-Fraser M. 1994. Neural crest cell formation and migration in the developing embryo [J]. American Societies for Experimental Biology (FASEB), 8: 699-706.

Fischl J, Ishay J. 1971. The glucose levels and carbohydrates autolysis in Vespa orientalis hemolymph [J]. Insectes Sociaux, 18: 203-214. 
Guiglia D. 1972. Les Guêpes sociales (Hymenoptera, Vespidae) [M]. Paris: Masson et Cie Editeurs.

Ikan R, Ishay J. 1967. Pteridines and purines of the queen of the Oriental hornet Vespa orientalis [J]. Journal of Insect Physiology, 13: 159-169.

Ishay J. 1964. Observations sur la biologie de la Guêpe orientale Vespa orientalis enIsraël [J]. Insectes Sociaux, 11: 193-206.

Ishay JS, Galushko D, Ermakov N, Bergmann DJ. 2004. Yellow pigment granules in hornets: their origin and development [J]. Journal of Electron Microscopy, 53: 649-657.

Ishay JS, Litinetsky L, Steinberg D. 1999. Architecture and composite structure of hornet cuticle (Insecta, Hymenoptera) [J]. Composite Structures, 46: 387-394.

Jongebloed WL, Kalicharan D. 1994. Tannic acid/arginine/osmium tetroxidefixation of rat tissue by the microwave procedure [J]. Beitrage Electronmikroskop Direktabbteilung Oberfl, 27: 243-252.

LeGuyader S, Jesuthasan S. 2002. Analysis of xanthophore and pterinosome biogenesis in zebrafish using methylene blue and pteridine autofluorescence [J]. Pigment Cell Research, 15: 27-31.
Rej R, Vanderlinde RE. 1975. Effects of buffers on aspartate aminotransferase activity and association of the enzyme with pyridoxal phosphate [J]. Clinical chemistry, 21: 1585-1591.

Schliva M, Euteneuer U. 1979. Hybrid pigment organelles in an invertebrate [J]. Cell Tissue Research, 196: 541-543.

Snyder AW, Pask C. 1972. Light absorption in the bee photoreceptor [J]. Journal of Optical Society of America, 62: 998-1008.

Spradbery JP. 1973. An Account of the Biology and Natural History of Solitary and Social wasps [M]. London: Sidgwick and Jackson.

Volynchik S, Plotkin M, Bergman DJ, Ishay JS. 2008. Hornet flight activity and its correlation with UVB radiation, temperature and relative humidity [J]. Photochemistry and Photobiology, 84: 81-85.

Wijnen B, Leertouwer HL, Stavenga DG. 2007. Colors and pterin pigmentation of pierid butterfly wings [J]. Journal of Insect Physiology, 53: 1206-1217.

Wroblewski F, Due LA. 1953. Lactic dehydrogenase activity in blood [J] Proceedings of the Society for Experimental Biology and Medicine, 90: $210-215$.

\section{中国科学院昆明灵长类研究中心获得国际实验动物组织完全认证}

2008 年 11 月底, 经过国际专家组严格的现场考核, 中国科学院昆明灵长类研究中心获得了国际实验 动物组织的完全认证 (Full Accreditation), 成为中国科学院及云南省首个通过国际实验动物评估和认证委 员会 (AAALAC) 认证的科研机构。这次对昆明灵长类研究中心评审的内容主要包括实验动物生产和使用 的设施设备等硬件条件，实验动物的生产、使用、管理和动物福利等的软件建设。通过评审，专家组对昆 明灵长类研究中心实验动物生产和使用设施、设备、管理、协调、培训、质量控制、环境控制、动物福利、 兽医照顾、职业健康、数据记录等工作给予了充分肯定。

AAALAC ( Association for Assessment and Accreditation of Laboratory Animal Care ) International, 是设 立在美国的国际实验动物评估和认证委员会。其宗旨是通过对实验动物生产和使用的机构进行统一的评估 与认证, 以保证实验动物的管理和使用的规范化与标准化, 保证实验动物从业人员的安全和健康。因此, 通过国际 AAALAC 严格的评审及认证，不仅表明了昆明灵长类研究中心在实验动物管理上达到了国际标 准与规范, 同时也表明我中心开展动物实验科学研究能力的提高。目前, 世界上已有 29 个国家的 770 多 个机构通过了 AAALAC 认证。中国已有 12 个机构通过了 AAALAC 认证。 